\title{
Geoscience education across the globe - results of the IUGS-COGE/IGEO survey
}

\author{
Director of the Earth Science Education Unit, Keele University, Keele, ST5 5BG, UK.E-mail: chris@ cjhking.plus.com
}

An international survey of school-level geoscience education acquired data from 32 countries across the globe. Whilst the data is likely to be biased towards those countries which have geoscience educators active enough to respond to the questionnaire survey, the data nevertheless shows that geoscience is taught in a wide variety of contexts across the world, linked to science, geography or both. The majority of children in the countries surveyed had compulsory geoscience education in their curricula, had national standards in geoscience education, and covered a reasonable level of geoscience terminology in their studies. Optional geoscience courses were taught in most countries, but were only generally available to small numbers of 16-18 year olds. Undergraduate geoscience education courses were available in all the countries surveyed, together with graduate education in all but one. There was a wide variety of outreach initiatives recorded, with those in museums reported to be most successful. A general improvement was possibly discernible, but there is ongoing need of support from national and international geoscience organisations, together with need for increased funding and infrastructure and the raising of global awareness of the importance of geoscience education.

\section{Introduction}

The survey carried out in 2012 includes data from 32 countries across the globe.

The first international survey was carried out as part of the formation of the International Geoscience Education Organisation (IGEO) in Sydney in 2000. The IUGS Commission on Geoscience Education and Technology Transfer (IUGS-COGE) was formed in 2004 and a collaboration was developed between IGEO and IUGSCOGE to undertake a second survey, as the basis of a bid for International Year of Planet Earth (IYPE) funding. The second survey was carried out over 2005/6 and eventually included data from 27 countries. On the basis of the returns from these countries, a bid was submitted to the IYPE to run pilot workshops in geoscience education in three countries: the Philippines, South Africa and Trinidad and Tobago. The bid was unsuccessful.
During 2011, when a review was undertaken of the progress of IUGS-COGE, the Commission was asked to write an article for Episodes using the data collected in the international education survey. Rather than just depending upon the data collected in 2006, this seemed like an opportune time to update and expand the survey. Thus all the contributors to the 2006 survey were invited to update their data, whilst new members of IGEO and IUGS-COGE were contacted and asked to complete a questionnaire response as well.

The Third International Geoscience Education survey that resulted has now been published on the IGEO website (IGEO website) so that all those who contributed the data, and other interested people, can use the data collected, should they wish to.

No similar survey of the international state of geoscience education appears to have been undertaken or published previously.

\section{The data}

The survey published on the IGEO website contains data from the 32 countries listed in Table 1 and shown in Figure 1. Twenty countries provided data in 2012; for 12 countries, only the data from 2006 is available. All the contributors who kindly provided the data are acknowledged at the foot of this publication - but should not be blamed for any inaccuracies.

Inaccuracies may occur in the data or in the interpretation because:

- some questions were not clearly understood by some contributors, probably because English is not their first language;

- some of the answers provided were unclear, probably for the same reason;

Table 1. Countries which provided data for the geoscience education survey, with date of latest update

\begin{tabular}{|l|c|l|c|}
\hline Country & $\begin{array}{c}\text { Date of latest } \\
\text { data update }\end{array}$ & Country & $\begin{array}{c}\text { Date of latest } \\
\text { data update }\end{array}$ \\
\hline Argentina & 2012 & Malawi & 2012 \\
Australia & 2006 & New Zealand & 2012 \\
Bangladesh & 2012 & Norway & 2012 \\
Belgium & 2006 & Philippines & 2012 \\
Brazil & 2012 & Portugal & 2006 \\
Czech Republic & 2006 & Romania & 2006 \\
England & 2012 & Russia & 2012 \\
Estonia & 2006 & Saudi Arabia & 2006 \\
France & 2006 & Scotland & 2006 \\
Germany & 2012 & South Africa & 2012 \\
India & 2012 & Sri Lanka & 2012 \\
Indonesia & 2012 & Spain & 2012 \\
Israel & 2012 & Taiwan & 2012 \\
Italy & 2012 & Trinidad and Tobago & 2006 \\
Japan & 2006 & Uruguay & 2006 \\
Korea & 2012 & United States & 2012 \\
\hline
\end{tabular}




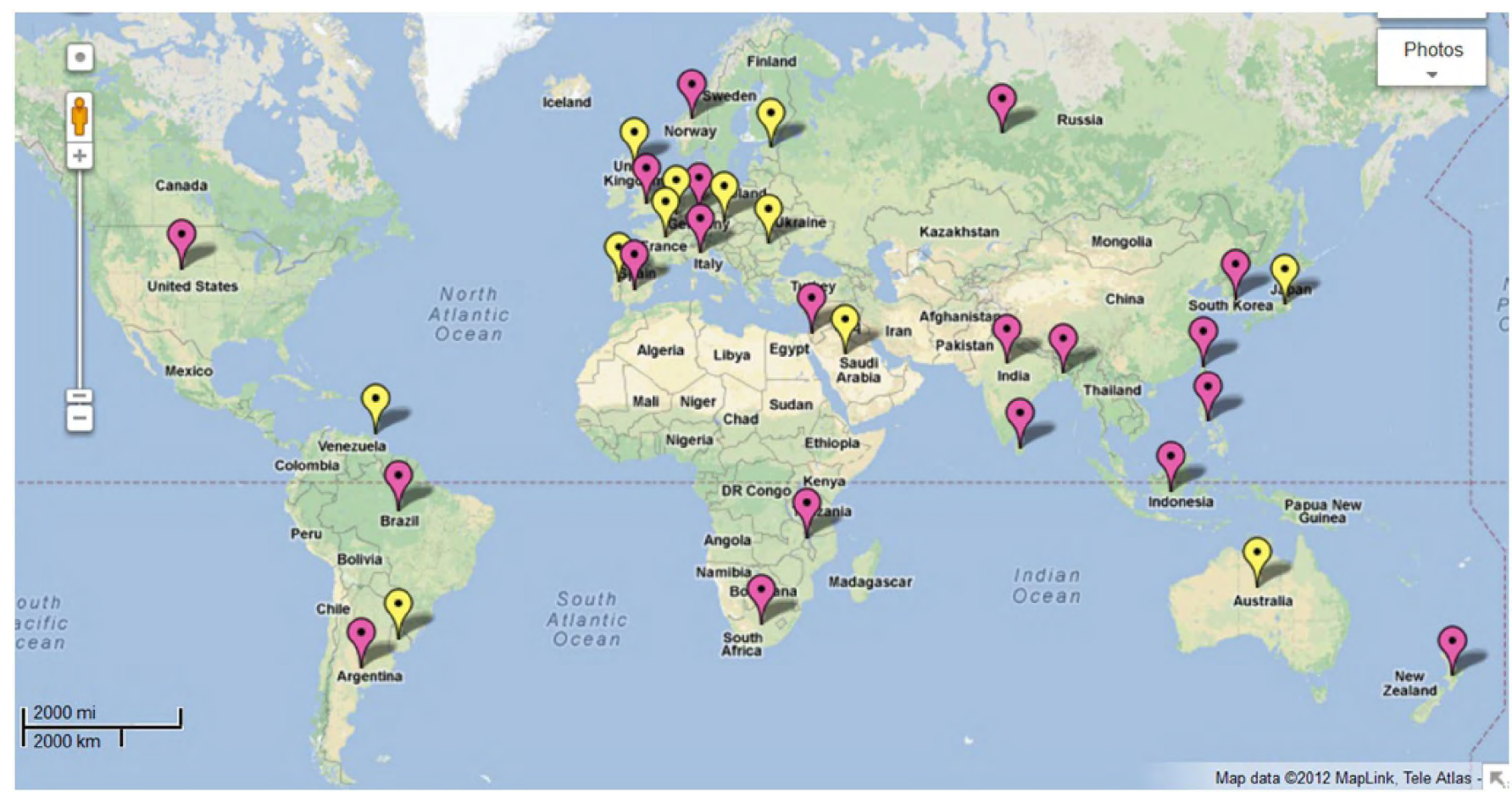

Figure 1. The distribution of countries which provided data for the geoscience education survey, with date of latest update schools - with thanks to Googlemaps. Countries providing 2012 data shown in pink, countries with 2006 data in yellow. This map can be found at: https:/ /maps.google.co.uk/maps/myplaces?vpsrc=3\&ctz=-60\&abauth=50155a03et2mAy988IYCS2vq4qAgZS4UXIw\&vps=1\&num=10

- in order to summarise the data, simplifications were necessary, which may have led to inaccurate oversimplification;

- where a country has several states (eg. Germany, India, USA), the contributors pointed out that, because of variations across their countries, they have done their best to present a national picture, but this often just reflects the situation in some states.

Please report any inaccuracies to the author so that the data published on the IGEO website can be corrected and so that any further research based on this data is not compromised.

Note that the data may be biased by:

- colleagues from those countries willing to submit questionnaires; where countries have not participated, this may mean that school-level earth science education is less healthy;

- the experience and perceptions of those completing the questionnaires, ranging from Earth science teachers, to Heads of University Geoscience Departments and from teacher educators to government officials.

\section{Data and analysis}

\section{Teaching approach}

It was possible to identify eight different approaches to the school teaching of Earth science across the globe, as shown in Table 2, with the distribution shown in Figure 2.

The approaches and distributions show that Earth science is taught in a wide variety of different contexts across the world. Some patterns can be discerned, as follows:

- most Latin-American and southern European countries teach Earth science as part of 'Natural Science' where it is taught mainly by biology teachers;
- east Asian countries generally teach Earth science within science, where it is taught mainly by Earth science specialist teachers;

- in many countries, Earth science is taught both within science, by science specialist teachers, and in geography, by geography teachers;

- in some countries (Northern Europe), it is mainly taught only in geography.

Table 2. Approach to the teaching of Earth science in schools

\begin{tabular}{|l|l|}
\hline Earth science teaching approach & Countries \\
\hline $\begin{array}{l}\text { Compulsory - part of Natural Sciences - } \\
\text { taught mostly by biology teachers }\end{array}$ & $\begin{array}{l}\text { Argentina, Brazil, Czech } \\
\text { Republic, France, Italy, } \\
\text { Portugal, Spain }\end{array}$ \\
\hline $\begin{array}{l}\text { Compulsory - part of chemistry and } \\
\text { geography - taught mostly by these } \\
\text { teachers }\end{array}$ & England, Sri Lanka \\
\hline $\begin{array}{l}\text { Compulsory - part of general science } \\
\text { and geography - taught mostly by } \\
\text { these teachers }\end{array}$ & $\begin{array}{l}\text { Bangladesh, India, } \\
\text { New Zealand, Norway, }\end{array}$ \\
\hline $\begin{array}{l}\text { Compulsory - part of general science - } \\
\text { taught mostly by these teachers }\end{array}$ & $\begin{array}{l}\text { Israel, Philippines, } \\
\text { South Africa }\end{array}$ \\
\hline $\begin{array}{l}\text { Compulsory - part of science - taught } \\
\text { mostly by Earth science teachers }\end{array}$ & Japan, South Korea, Taiwan \\
\hline $\begin{array}{l}\text { Compulsory - part of geography - } \\
\text { taught mostly by geography teachers }\end{array}$ & $\begin{array}{l}\text { Belgium, Germany, } \\
\text { Indonesia }\end{array}$ \\
\hline $\begin{array}{l}\text { Compulsory - part of primary science } \\
\text { and geography - taught mostly by } \\
\text { primary teachers }\end{array}$ & Scotland \\
\hline \begin{tabular}{l} 
Not compulsory \\
\hline
\end{tabular} & Malawi \\
\hline
\end{tabular}




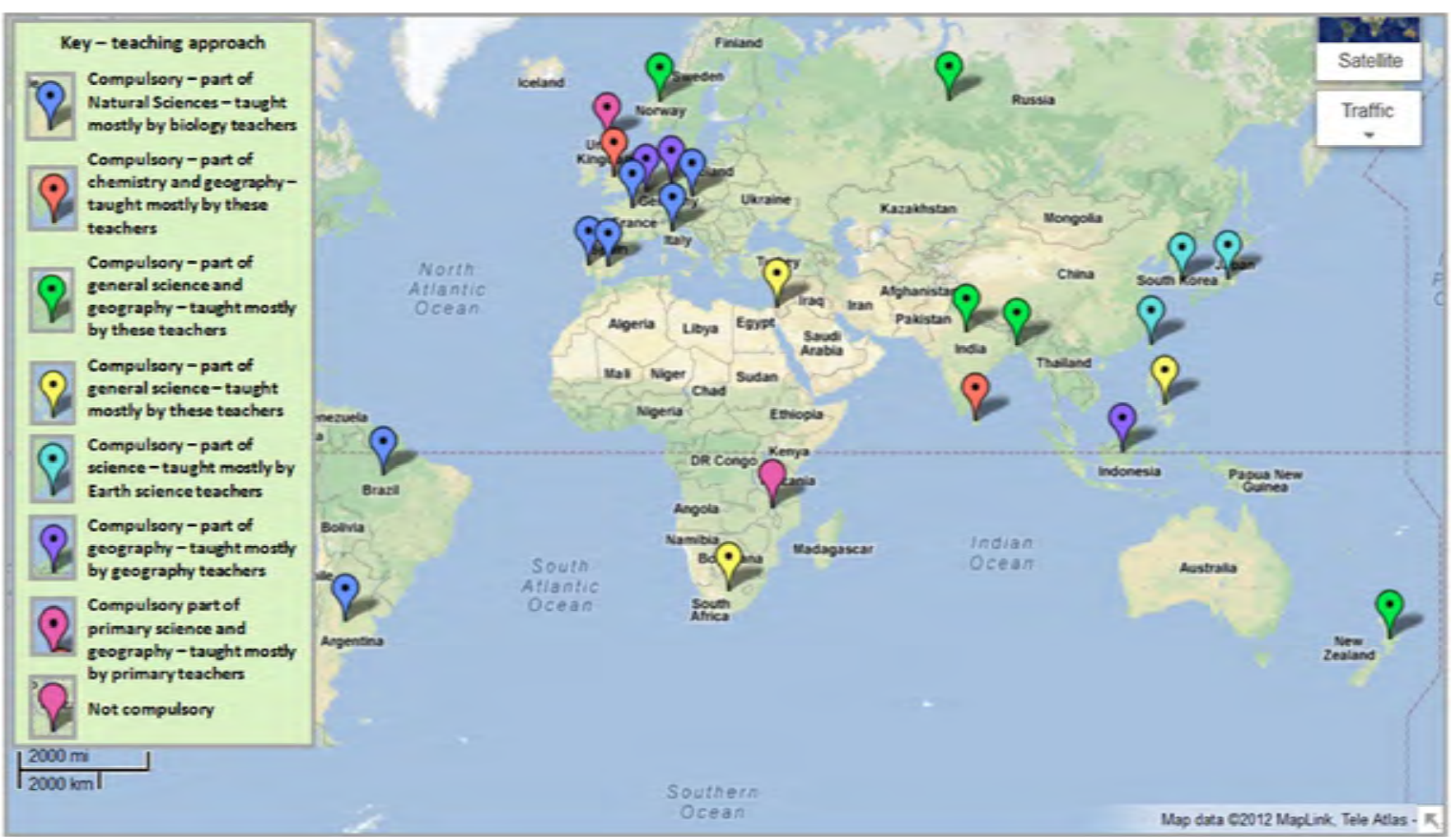

Figure 2. The distribution of approaches to the teaching of Earth science in schools - with thanks to Googlemaps. This map can be found at: https://maps.google.co.uk/maps/myplaces? vpsrc=3\&ctz=-60\&abauth=50155a03et $2 \mathrm{mAy} 988 I Y C S 2 v q 4 q \mathrm{AgZS} 4 \mathrm{UXIw} \& \mathrm{vps}=1 \mathrm{Q}$ num $=10$

These different contexts may affect the teaching style. For example, where Earth science is taught through science, more practical, hands-on approaches might be anticipated, whereas geography teachers may favour more map/ distribution/ hazards-based approaches.

\section{National standards in Earth science}

The majority of countries which contributed to the survey do have national standards for Earth science education, as shown in Table 3.

\section{Table 3. National standards in school-level Earth science}

\begin{tabular}{|ll|c|}
\hline \multicolumn{2}{|c|}{$\begin{array}{c}\text { Countries with National } \\
\text { Standards in Earth Science }\end{array}$} & $\begin{array}{l}\text { Countries with no National } \\
\text { Standards in Earth Science }\end{array}$ \\
\hline Argentina & Norway & Bangladesh \\
Brazil & Philippines & France \\
Czech Republic & Portugal & Germany \\
England & Romania & India \\
Estonia & Russia & Scotland \\
Indonesia & Saudi Arabia & \\
Israel & South Africa & \\
Italy & Sri Lanka & \\
Japan & Spain & \\
Korea & Taiwan & \\
Malawi & Trinidad \& Tobago & \\
New Zealand & United States & \\
\hline
\end{tabular}

\section{Ages of children covered by compulsory Earth science education}

The compulsory coverage of Earth science is shown in Table 4.
The data shows that half the 5-7 year olds (52\%) in the countries covered by the survey had compulsory Earth science education; four fifths of the 7-11 year olds (80\%) were similarly covered, as were more than four fifths (84\%) of 11-14 year olds and nearly three quarters $(74 \%)$ of $14-16$ year olds. However, only about a third of 16-18 year olds (35\%) had compulsory Earth science coverage.

Table 4. The compulsory coverage of Earth science education (the 'Yes' responses are shaded)

\begin{tabular}{|c|c|c|c|c|c|}
\hline Country & $\begin{array}{c}5-7 \\
\text { year olds }\end{array}$ & $\begin{array}{c}7-11 \\
\text { year olds }\end{array}$ & $\begin{array}{c}11-14 \\
\text { year olds }\end{array}$ & $\begin{array}{c}14-16 \\
\text { year olds }\end{array}$ & $\begin{array}{c}16-18 \\
\text { year olds }\end{array}$ \\
\hline Argentina & Yes & Yes & Yes & Yes & Yes \\
\hline Australia & Yes & Yes & Yes & Yes & No \\
\hline Bangladesh & No & Yes & Yes & No & \\
\hline Belgium & No & Yes & Yes & Yes & \\
\hline Brazil & No & No & No & No & \\
\hline Czech Republic & Partly yes & Yes & Yes & Yes & Yes \\
\hline England & Yes & Yes & Yes & Yes & No \\
\hline Estonia & No & Yes & Yes & Yes & Yes \\
\hline France & No & No & No & No & No \\
\hline Germany & No & Yes & Yes & Yes & $\begin{array}{c}\text { Depends on the } \\
\text { State }\end{array}$ \\
\hline India & Yes & Yes & Yes & Yes & No \\
\hline Indonesia & No & Yes & Yes & Yes & \\
\hline Israel & Yes & Yes & Yes & Yes & Yes \\
\hline Italy & Yes & Yes & Yes & Yes & $\begin{array}{c}\text { Yes (in some } \\
\text { schools) }\end{array}$ \\
\hline Japan & Yes & Yes & Yes & Yes & Yes \\
\hline Korea & Yes & Yes & Yes & Yes & Yes \\
\hline Malawi & No & No & No & No & No \\
\hline New Zealand & Yes & Yes & Yes & Yes & $\begin{array}{c}\text { As part of } \\
\text { Science or Bio }\end{array}$ \\
\hline Norway & No & Yes & Yes & Yes & Optional \\
\hline Philippines & Yes & Yes & Yes & Yes & $\begin{array}{l}\text { Depends on } \\
\text { school }\end{array}$ \\
\hline Portugal & Yes & Yes & Yes & Yes & No \\
\hline Romania & Yes & Yes & Yes & Yes & Yes \\
\hline Russia & Yes & Yes & Yes & Yes & \\
\hline Saudi Arabia & No & No & No & No & Yes \\
\hline Scotland & Yes & Yes & Yes & No & No \\
\hline South Africa & Yes & Yes & Yes & Yes & No \\
\hline Sri Lanka & No & No & Yes & Yes & Yes \\
\hline Taiwan & & Yes & Yes & Yes & \\
\hline Trinidad \& Tobago & No & Yes & No & No & No \\
\hline Uruguay & Yes & Yes & Yes & Yes & Yes \\
\hline United States & \multicolumn{3}{|c|}{ Yes - in many states it is includ } & No & No \\
\hline Totals/31 & $16=52 \%$ & $25=80 \%$ & $26=84 \%$ & $23=74 \%$ & $11=35 \%$ \\
\hline
\end{tabular}


The data therefore indicates that there is reasonably good coverage in compulsory Earth science education across the globe - particularly for 7-16 year olds.

\section{Textbook availability}

The availability of textbooks and other teaching materials supporting Earth science education across the world is shown in Table 5. However, recent studies have suggested that many of these textbooks may contain poor quality material, with errors and oversimplifications (King, 2010).

Of the countries which contributed to the survey, more than half of 5-11 year olds (58\% of 5-7 year olds, $52 \%$ of 7-11 year olds) had no textbooks and teaching materials, or materials of only poor quality; a third of 11-16 year olds (35\% of 11-14 year olds and 42\% of $14-16$ year olds) had no or poor quality materials, whilst more than a third (39\%) of 14-16 year olds were in a similar position.

If textbooks and teaching materials are poor or non-existent in more than a third of the countries surveyed, it might be construed that teaching is also poor in those areas. Even in those countries where better teaching materials are available, there may also be cause for concern if these materials are of poor quality and contain misconceptions.

\section{Benchmarking on the basis of geoscience terms in the curriculum}

The benchmarking attempt was made on the basis of the 124 geoscience terms shown in Table 6. Contributors were asked to indicate at which levels, if at all, these terms appeared in the

Table 5. Availability of textbooks and other teaching materials (the positive responses are shaded)

\begin{tabular}{|c|c|c|c|c|c|}
\hline Country & $5-7$ years & $7-11$ years & $11-14$ years & $14-16$ years & $16-18$ years \\
\hline Argentina & \multicolumn{5}{|c|}{ Poor } \\
\hline Australia & No & Some & Some & Some & No \\
\hline Belgium & Some & Some & Some & Some & Some \\
\hline Brazil & & & One & & \\
\hline Czech Republic & Some & Some & Some & Some & Some \\
\hline England & No & Some & Some & Some & Two \\
\hline Estonia & No & Yes & Yes & Yes & Yes \\
\hline France & & & Yes & Yes & Yes \\
\hline Germany & & $\begin{array}{l}\text { Book and CD- } \\
\text { ROM }\end{array}$ & & & $\begin{array}{l}\text { CD-ROM (11 } \\
\text { Modules) }\end{array}$ \\
\hline India & \multicolumn{5}{|c|}{ A range of materials, including textbooks, guides and other materials is generally available. } \\
\hline Indonesia & No & No & $\begin{array}{c}\text { Geography } \\
\text { textbooks }\end{array}$ & \multicolumn{2}{|c|}{ A geography textbook } \\
\hline Israel & Yes & Yes - extensive & Yes - extensive & \multicolumn{2}{|c|}{ Yes - extensive } \\
\hline Italy & \multicolumn{5}{|c|}{ Textbooks, CD-ROMs, videotapes, DVDs } \\
\hline Japan & \multicolumn{5}{|c|}{ Yes - by Ministry of Education } \\
\hline Korea & \multicolumn{2}{|c|}{ Textbooks by the national agency } & \multicolumn{3}{|c|}{$\begin{array}{c}\text { Textbooks and other teaching materials by several } \\
\text { publishers }\end{array}$} \\
\hline Malawi & \multicolumn{5}{|c|}{ Texts are available (geography) at all levels but are out-dated. } \\
\hline New Zealand & & Poor & One & One & \\
\hline Norway & \multicolumn{5}{|c|}{ Several textbooks in geography and general science are available } \\
\hline Philippines & Yes & Yes & Yes & \multicolumn{2}{|c|}{ To be developed } \\
\hline Portugal & Textbooks & Textbooks & $\begin{array}{l}\text { Textbooks/ } \\
\text { worksheets }\end{array}$ & $\begin{array}{l}\text { Textbooks/ } \\
\text { worksheets }\end{array}$ & Textbooks \\
\hline Romania & & Yes & Yes & Yes & Yes \\
\hline Russia & Yes & $\begin{array}{c}\text { Text book in } \\
\text { nature }\end{array}$ & $\begin{array}{l}\text { Text book in } \\
\text { geography }\end{array}$ & $\begin{array}{l}\text { Text book in } \\
\text { geography }\end{array}$ & $\begin{array}{l}\text { Text book in } \\
\text { geography }\end{array}$ \\
\hline Saudi Arabia & & & & & Yes, textbook \\
\hline Scotland & Yes & & & & \\
\hline South Africa & \multicolumn{2}{|c|}{ Yes } & \multicolumn{3}{|c|}{ Yes - of variable quality } \\
\hline Sri Lanka & No & No & $\begin{array}{l}\text { Basic concepts } \\
\text { included }\end{array}$ & $\begin{array}{l}\text { Basic concepts } \\
\text { included }\end{array}$ & $\begin{array}{c}\text { Geography } \\
\text { textbook }\end{array}$ \\
\hline Spain & \multicolumn{2}{|c|}{ No } & \multicolumn{3}{|c|}{$\begin{array}{c}\text { Textbooks, CD-ROMs, videotapes, DVDs in Spanish + } \\
\text { other langs. }\end{array}$} \\
\hline Taiwan & One & One & One & One & \\
\hline Trinidad \& Tobago & $\begin{array}{l}\text { Textbooks, } \\
\text { worksheets }\end{array}$ & $\begin{array}{l}\text { Textbooks, } \\
\text { worksheets }\end{array}$ & $\begin{array}{l}\text { Textbooks, } \\
\text { worksheets }\end{array}$ & $\begin{array}{l}\text { Textbooks, } \\
\text { worksheets }\end{array}$ & $\begin{array}{l}\text { Textbooks, } \\
\text { worksheets }\end{array}$ \\
\hline Uruguay & & & Geography & Geography & \\
\hline United States & $\begin{array}{c}\text { FOSS (Full } \\
\text { Option Science } \\
\text { System) }\end{array}$ & $\begin{array}{c}\text { ESIP (Earth } \\
\text { Systems } \\
\text { Programme } \\
\text { Implementation } \\
\text { Project) Project }\end{array}$ & $\begin{array}{l}\text { Investigating } \\
\text { Earth Systems } \\
\text { (IES) curriculum } \\
\text { Project CUES }\end{array}$ & $\begin{array}{c}\text { EarthComm } \\
\text { curriculum } \\
\text { http://edmall.gsf } \\
\text { c.nasa.gov/aacps } \\
\text { /curriculum.html }\end{array}$ & $\begin{array}{c}\text { Advanced } \\
\text { Placement } \\
\text { Environmental } \\
\text { Science }\end{array}$ \\
\hline $\begin{array}{l}\text { Good quality } \\
\text { total/31 }\end{array}$ & $13=42 \%$ & $15=48 \%$ & $20=65 \%$ & $18=\mathbf{5 8 \%}$ & $19=61 \%$ \\
\hline
\end{tabular}


Table 6. Terms used to benchmark the Earth science content of the curriculum across the world

\begin{tabular}{|c|c|c|c|c|c|}
\hline $\begin{array}{l}\text { General material/ } \\
\text { process terms } \\
\text { (37) }\end{array}$ & $\begin{array}{l}\text { Plate tectonic and } \\
\text { Earth structure } \\
\text { terms (12) }\end{array}$ & $\begin{array}{l}\text { Geological time } \\
\text { and evolution } \\
\text { terms (8) }\end{array}$ & $\begin{array}{l}\text { Natural resource and } \\
\text { natural hazard terms } \\
\text { (28) }\end{array}$ & $\begin{array}{l}\text { Rock types } \\
\text { (19) }\end{array}$ & $\begin{array}{l}\text { Approach - terms used in an } \\
\text { Earth science context or in a } \\
\text { general context that applies } \\
\text { to Earth science (20) }\end{array}$ \\
\hline 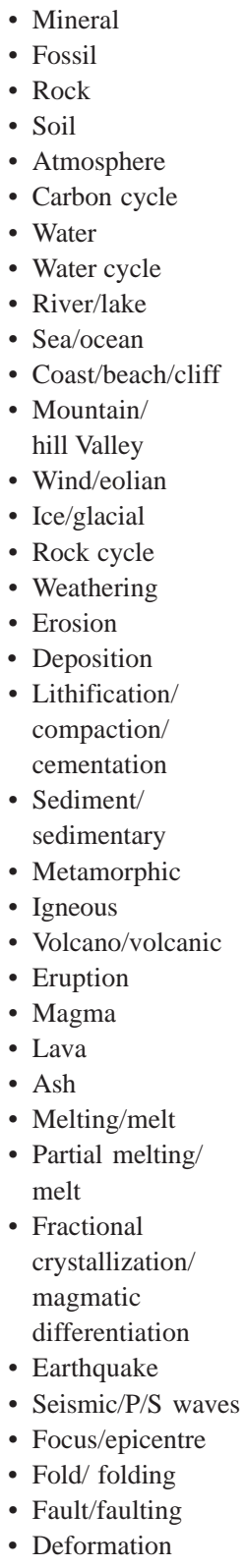 & $\begin{array}{l}\text { - } \text { Plate tectonics/ } \\
\text { tectonic plate } \\
\text { - Lithosphere } \\
\text { - Asthenosphere } \\
\text { - Subduction } \\
\text { - Magnetic stripes } \\
\text { - Polar wandering } \\
\text { - Mountain building/ } \\
\text { orogeny } \\
\text { - Continental/ } \\
\text { oceanic plate } \\
\text { - Crust } \\
\text { - Mantle } \\
\text { - Core } \\
\text { - Outer core/ } \\
\text { inner core }\end{array}$ & $\begin{array}{l}\text { - Geological time/ } \\
\text { - } \text { timescale } \\
\text { - Dating } \\
\text { - Correlation } \\
\text { - Etratigraphy } \\
\text { - Earth history } \\
\text { - Nolution } \\
\text { - } \text { Natural selection } \\
\text { Fossil record }\end{array}$ & $\begin{array}{l}\text { - Energy source/supply } \\
\text { - Renewable/ } \\
\text { non renewable } \\
\text { - Sustainable/ } \\
\text { sustainability } \\
\text { - Groundwater } \\
\text { - Pollution } \\
\text { - Acid rain } \\
\text { - Ore } \\
\text { - Mine/mining } \\
\text { - Quarry/quarrying } \\
\text { - Borehole/ well } \\
\text { - Fossil fuel } \\
\text { - Coal } \\
\text { - Oil/ crude oil } \\
\text { - Gas/ natural gas } \\
\text { - Hydroelectric power } \\
\text { - Solar power } \\
\text { - Wave power } \\
\text { - Wind power } \\
\text { - Power from biomass } \\
\text { - Landslide/ landslip/ } \\
\text { rock fall } \\
\text { - Lahar } \\
\text { - Nueé ardente } \\
\text { - Tsunami } \\
\text { - Storm } \\
\text { - Flood } \\
\text { - Natural hazard } \\
\text { - Prediction/ forecast } \\
\text { - Disaster planning } \\
\text { (or similar) }\end{array}$ & $\begin{array}{l}\text { - Sandstone } \\
\text { - Limestone } \\
\text { - Shale/ mudstone/ } \\
\text { clay } \\
\text { - Conglomerate } \\
\text { - Coal } \\
\text { - Peat } \\
\text { - Slate } \\
\text { - Schist } \\
\text { - Gneiss } \\
\text { - Marble } \\
\text { - Quartzite/ } \\
\text { metaquartzite } \\
\text { - Granite } \\
\text { - Gabbro } \\
\text { - Basalt } \\
\text { - Dolerite } \\
\text { - Volcanic ash } \\
\text { - Andesite } \\
\text { - Rhyolite } \\
\text { - Peridotite }\end{array}$ & $\begin{array}{l}\text { - Sort/ sorting } \\
\text { - Identify/ identification/ } \\
\text { recognise } \\
\text { - Classify/ classification } \\
\text { - Describe/ description } \\
\text { - Measure } \\
\text { - Explore } \\
\text { - Explain/ explanation } \\
\text { - Fieldwork/ in the field } \\
\text { - Plan } \\
\text { - Observe } \\
\text { - Experiment with } \\
\text { - Interpret } \\
\text { - Analyze } \\
\text { - Give evidence } \\
\text { - Predict } \\
\text { - Apply } \\
\text { - Evaluate } \\
\text { - Enquiry } \\
\text { - History of science } \\
\text { - Map/ mapwork }\end{array}$ \\
\hline
\end{tabular}

curriculum. 25 questionnaire responses were received, and the results are shown in Table 7.

The data shows that, on average, $79 \%$ of the 124 terms are found somewhere in the curriculum, broken down to $6 \%$ of the terms for 5-7 year olds; $23 \%$ of the terms for 7-11 year olds; $45 \%$ for $11-14$ year olds; $49 \%$ for $14-16$ year olds; and $58 \%$ for $16-18$ year olds.

It is not surprising that an increasing number of the terms appear in the curriculum as the ages of children increases. It is also not surprising that all the terms don't necessarily appear at the higher levels, since some may be simpler terms, more appropriate for younger children.

Overall, it could be argued that a reasonable number of geoscience terms is covered by Earth science curricula across the world, even though the situation is rather 'patchy'. This 'patchy' nature can partly be explained by some countries publishing detailed content-filled curricula whilst others have adopted a more 'umbrella' approach, of publishing broad Earth science statements and leaving teachers and examiners to provide the necessary detail.

\section{Availability of optional geoscience education courses}

The availability of optional courses in school/college-level geoscience education is shown in Table 8 .

The data indicates that, of the countries covered by the survey, 
Table 7. Summary of benchmarking data (based on the 124 terms listed in Table 6)

\begin{tabular}{|c|c|c|c|c|c|c|}
\hline Country & $\begin{array}{c}\text { Term is } \\
\text { present in } \\
\text { curriculum }\end{array}$ & $\begin{array}{c}\text { For } \\
5-7 \text { year } \\
\text { olds }\end{array}$ & $\begin{array}{c}\text { For } \\
7-11 \text { year } \\
\text { olds }\end{array}$ & $\begin{array}{c}\text { For } \\
11-14 \\
\text { year olds }\end{array}$ & $\begin{array}{c}\text { For } \\
14-16 \\
\text { year olds }\end{array}$ & $\begin{array}{c}\text { For } \\
16-18 \\
\text { year olds }\end{array}$ \\
\hline Bangladesh & 11 & 0 & 0 & 11 & 0 & 0 \\
\hline Belgium & 108 & 15 & 44 & 30 & 56 & 105 \\
\hline Brazil & 72 & 0 & 0 & 61 & 15 & 0 \\
\hline England & 60 & 7 & 17 & 40 & 25 & 0 \\
\hline Estonia & 120 & 0 & 47 & 80 & 116 & 120 \\
\hline France & 124 & 1 & 7 & 71 & 111 & 124 \\
\hline Germany (Lower Saxony) & 42 & 0 & 2 & 27 & 7 & 12 \\
\hline Indonesia & 112 & 5 & 10 & 65 & 93 & 112 \\
\hline Israel & 112 & 18 & 62 & 92 & 94 & 112 \\
\hline Italy & 55 & 15 & 5 & 23 & 14 & 28 \\
\hline Korea & 123 & 20 & 79 & 113 & 121 & 123 \\
\hline Malawi & 85 & 8 & 35 & 47 & 53 & 85 \\
\hline New Zealand & 91 & 7 & 25 & 74 & 43 & 37 \\
\hline Norway & 48 & 1 & 10 & 12 & 24 & 43 \\
\hline Portugal & 105 & 20 & 54 & 73 & 87 & 85 \\
\hline Romania & 104 & 3 & 18 & 73 & 91 & 104 \\
\hline Russia & 128 & 6 & $33-35$ & 60 & 26 & 0 \\
\hline Scotland & 31 & 0 & 1 & 14 & 0 & 0 \\
\hline South Africa & 96 & 2 & 3 & 49 & 76 & 107 \\
\hline Saudi Arabia & 118 & 1 & 9 & 11 & 11 & 86 \\
\hline Sri Lanka & 102 & 5 & 15 & 43 & 91 & 102 \\
\hline Spain & 124 & 41 & 85 & 103 & 116 & 124 \\
\hline Taiwan & 96 & 15 & 40 & 83 & 107 & 97 \\
\hline Trinidad \& Tobago & 76 & 19 & 25 & 46 & 36 & 48 \\
\hline Uruguay & 108 & 0 & 66 & 94 & 103 & 103 \\
\hline Mean/25 & $89=72 \%$ & $8=6 \%$ & $28=23 \%$ & $56=45 \%$ & $61=49 \%$ & $72=58 \%$ \\
\hline
\end{tabular}

nearly two thirds $(61 \%)$ have optional geoscience education courses and that these are mostly available to $16-18$ year olds in small numbers of schools. Where they are available, they usually can be used to contribute to university entry qualifications. Whilst the global availability of such courses is to be welcomed, it is concerning to note that they are generally only available to small numbers of $16-18$ year olds in most countries.

\section{Earth science outreach}

Different types of potential Earth science outreach are shown in Tables 9 and 10 with a perception of their effectiveness and how widespread they are.

The data indicates that, where available, the different forms of outreach are widespread to fairly widespread across countries.

Table 9 shows that the most successful forms of Earth science outreach are run by museums in most of the countries surveyed (84\%) and that these outreach activities can be very effective; mostly they are effective to fairly effective.

Interactive science centres are available in more than half the countries and are effective to fairly effective. Meanwhile national parks and parks with an Earth science focus are available in around half the countries (national parks - 55\%, parks with an Earth science focus $-48 \%$ ), and are fairly effective.

Networks protecting Earth science sites are available in nearly a third of countries (32\%) and are effective to fairly effective.

Table 10 indicates that around a third of the countries have public understanding organisations focussing on Earth science (35\%), local "rockhound" groups (39\%), groups aimed at children (35\%) and
Public Understanding of Science events with Earth science content $(32 \%)$. In general these strategies are effective to fairly effective and widespread to fairly widespread.

These Earth science outreach strategies are to be applauded, particularly where they are effective and widespread, but clearly need more dissemination and support elsewhere. The most successful programmes recorded across the world are listed in Table 11.

\section{Undergraduate and graduate geoscience education}

Table 12 lists the numbers of undergraduate and graduate programmes found in the contributing countries.

The figures, although they range from 1 to perhaps 600 intuitions per country offering undergraduate education and 1 to 336 offering postgraduate education, are not very meaningful. At most they probably show that, the more developed and larger a country, the more institutions offer geoscience at Higher Education level.

In only two countries (Taiwan and Germany for geography) do the geoscience higher education institutions have a role in mentoring school teachers of Earth science. Elsewhere, no such links are recorded.

\section{Major problems facing school-level geoscience education}

The open-ended responses to this question were wide, varied and difficult to summarise. They do however, need to be set against recent successes in Australia, Norway and the Philippines. In Norway, the 
Table 8. The global availability of optional geoscience education courses (the positive responses are shaded)

\begin{tabular}{|c|c|c|c|c|}
\hline Country & $\begin{array}{l}\text { Are optional earth science or } \\
\text { geoscience courses offered in } \\
\text { schools/ colleges? }\end{array}$ & $\begin{array}{l}\text { At what age are } \\
\text { they available? }\end{array}$ & $\begin{array}{l}\text { Are they available to all/ most/ } \\
\text { a few/ hardly any pupils } \\
\text { across the system? }\end{array}$ & $\begin{array}{l}\text { Do earth science/ geoscience } \\
\text { courses satisfy college or } \\
\text { university science entrance } \\
\text { requirements? }\end{array}$ \\
\hline Argentina & No & & & \\
\hline Australia & Yes & $16-18$ year olds & Small number & Yes \\
\hline Bangladesh & No & & & \\
\hline Brazil & $\begin{array}{l}\text { No, but mining courses and } \\
\text { environmental sciences } \\
\text { training in some technical } \\
\text { colleges }\end{array}$ & $17-19$ year olds & Few & $\begin{array}{l}\text { No courses but some related } \\
\text { questions in exams }\end{array}$ \\
\hline Czech Republic & Very rarely & 17-19 year olds & & \\
\hline England & Yes & 16-18 year olds & Hardly any & Yes \\
\hline Estonia & No & & & \\
\hline France & No & & & \\
\hline Germany & $\begin{array}{l}\text { Yes (depends on the Federal } \\
\text { State) }\end{array}$ & $10-16$ year olds & No & No \\
\hline India & $\begin{array}{l}\text { No for schools, Yes for } \\
\text { colleges }\end{array}$ & 19 year olds & A few & Yes \\
\hline Indonesia & $\begin{array}{l}\text { Technical High Schools offer } \\
\text { Mine and Geology courses }\end{array}$ & $\begin{array}{l}\text { 15/16-18/19 year } \\
\text { olds (schools) }\end{array}$ & $\begin{array}{l}\text { Only for those who take } \\
\text { Technical High School }\end{array}$ & No \\
\hline Israel & Yes & $16-18$ year olds & Few & Yes \\
\hline Italy & No & & & \\
\hline Japan & Yes & $15-18$ year olds & $\begin{array}{l}\text { Only students who want to } \\
\text { major in earth science-related } \\
\text { studies at university take these } \\
\text { elective courses }\end{array}$ & $\begin{array}{l}\text { Around } 4 \% \text { of all students } \\
\text { chose earth science I as one of } \\
\text { their college entrance exam } \\
\text { areas in } 2008\end{array}$ \\
\hline Korea & Yes & 16-18 year olds & $\begin{array}{l}\text { Students who want to major } \\
\text { earth science-related studies at } \\
\text { the university take these } \\
\text { elective courses }\end{array}$ & $\begin{array}{l}\text { Around } 17 \% \text { of all students } \\
\text { chose earth science as one of } \\
\text { their college entrance exam } \\
\text { areas in } 2004\end{array}$ \\
\hline Malawi & Yes & After the age of 16 & $\begin{array}{l}\text { Available to all science } \\
\text { students }\end{array}$ & Yes \\
\hline New Zealand & $\begin{array}{l}\text { Yes, but now very reduced to } \\
\text { almost none }\end{array}$ & Years 11-13 & Depends on school & Yes \\
\hline Norway & Yes & $17-19$ year olds & Depends on the school & Yes \\
\hline Philippines & Yes & $13+$ years & No & No \\
\hline Portugal & In some professional schools & & & No \\
\hline Romania & Yes & $11-18$ year olds & & Yes \\
\hline Russia & Yes & $\begin{array}{l}\text { Secondary school } \\
\text { level }\end{array}$ & $\begin{array}{l}\text { Students who want to major } \\
\text { Earth science-related studies } \\
\text { at the university take elective } \\
\text { courses }\end{array}$ & Not enough \\
\hline Saudi Arabia & No & & & \\
\hline Scotland & Yes & $14+$ & Few & Yes \\
\hline South Africa & No & & & \\
\hline Spain & Yes & $16-18$ year olds & Only to science branch pupils & Yes \\
\hline Sri Lanka & No & & & \\
\hline Taiwan & Yes & Years 11 and 12 & & Yes \\
\hline $\begin{array}{l}\text { Trinidad \& } \\
\text { Tobago }\end{array}$ & No & & & \\
\hline United States & Available in some schools. & Varies & Depends on the school. & $\begin{array}{l}\text { Variable. Some universities/ } \\
\text { colleges do accept geology } \\
\text { others do not. }\end{array}$ \\
\hline Uruguay & No & & & \\
\hline Total/31 & $19=61 \%$ & $\begin{array}{l}\text { Mostly 16-18 year } \\
\text { olds }\end{array}$ & Generally small numbers & Mostly 'yes' \\
\hline
\end{tabular}


Table 9. The availability of Earth science outreach in museums, interactive science centers, national parks, parks with an Earth science focus and networks protecting Earth science sites (the paler the shade, the less effective/widespread - where limited data are available, this is shown in white) (Key: $V=$ very; $F=$ fairly; $E f=$ effective; $W i=$ widespread)

\begin{tabular}{|c|c|c|c|c|c|c|c|c|c|c|}
\hline Country & \multicolumn{2}{|c|}{ Museums } & \multicolumn{2}{|c|}{$\begin{array}{c}\text { Interactive } \\
\text { science centers }\end{array}$} & \multicolumn{2}{|c|}{\begin{tabular}{|l} 
National parks \\
\end{tabular}} & \multicolumn{2}{|c|}{$\begin{array}{c}\text { Parks with an } \\
\text { Earth Science } \\
\text { focus }\end{array}$} & \multicolumn{2}{|c|}{$\begin{array}{c}\text { Networks } \\
\text { protecting } \\
\text { Earth science } \\
\text { sites }\end{array}$} \\
\hline Argentina & & & & & & & & & & \\
\hline \begin{tabular}{|l|} 
Australia \\
\end{tabular} & Ef & $\mathrm{Wi}$ & Ef & $\mathrm{Wi}$ & FEf & $\mathrm{FWi}$ & & & & \\
\hline Bangladesh & \multicolumn{2}{|c|}{ One } & & & & & & & & \\
\hline Belgium & VEf & $\mathrm{VWi}$ & VEf & Wi & & & & & & \\
\hline Brazil & VEf & Wi & \multicolumn{2}{|c|}{ Some } & FEf & $\mathrm{FWi}$ & \multicolumn{2}{|c|}{ Four } & \multicolumn{2}{|c|}{ Yes } \\
\hline Czech Republic & Ef & Wi & & & FEf & Wi & & & & \\
\hline England & Ef & $\mathrm{FWi}$ & & & & & \multicolumn{2}{|c|}{ Several } & Ef & Wi \\
\hline Estonia & Ef & Wi & FEf & $\mathrm{Wi}$ & FEf & $\mathrm{Wi}$ & FEf & $\mathrm{Wi}_{\mathrm{i}}$ & & \\
\hline France & Ef & $\mathrm{FWi}$ & Ef & $\mathrm{FWi}$ & FEf & F Wi & FEf & $\mathrm{FWi}$ & FEf & $\mathrm{FWi}$ \\
\hline Germany & FEf & Wi & FEf & $\mathrm{FWi}$ & & & FEf & $\mathrm{FWi}$ & & \\
\hline India & \multicolumn{2}{|c|}{ Some } & \multicolumn{2}{|c|}{ Ef } & & & \multicolumn{2}{|c|}{ Ef } & & \\
\hline Indonesia & FEf & FWi & Ef & FWi & FEf & F Wi & FEf & FWi & Ef & $\mathrm{Wi}$ \\
\hline Israel & FEf & FWi & FEf & FWi & FEf & F Wi & FEf & $\mathrm{FWi}_{\mathrm{i}}$ & FEf & $\mathrm{FWi}$ \\
\hline Italy & V Ef & Wi & & & FEf & F Wi & FEf & $\mathrm{FWi}$ & FEf & $\mathrm{FWi}$ \\
\hline Japan & Ef & F Wi & Ef & FWi & FEf & F Wi & & & & \\
\hline Korea & VEf & $\mathrm{VWi}$ & FEf & $\mathrm{FWi}$ & FEf & F Wi & FEf & $\mathrm{FWi}$ & FEf & FWi \\
\hline \multicolumn{11}{|l|}{ Malawi } \\
\hline New Zealand & FEf & $\mathrm{FWi}$ & \multicolumn{2}{|c|}{ One } & & imal & \multicolumn{2}{|c|}{ One } & & \\
\hline Norway & FEf & FWi & FEf & FWi & & & \multicolumn{2}{|c|}{ Two } & & \\
\hline \begin{tabular}{|l|} 
Portugal \\
\end{tabular} & & & Ef & Wi & & & Ef & & & \\
\hline \begin{tabular}{|l|} 
Philippines \\
\end{tabular} & Ef & & Ef & & Ef & & & & & \\
\hline Romania & Ef & $\mathrm{Wi}_{\mathrm{i}}$ & FEf & FWi & Ef F & Wi & & & FEf & $\mathrm{FWi}$ \\
\hline Russia & FEf & F Wi & \multicolumn{2}{|c|}{ One } & & & \multicolumn{2}{|c|}{\begin{tabular}{l|l} 
FEf & F Wi \\
\end{tabular}} & & \\
\hline Saudi Arabia & FEf & $\mathrm{FWi}$ & \multirow{2}{*}{\multicolumn{2}{|c|}{ FEf }} & Ef & $\mathrm{Wi}$ & & & & \\
\hline \begin{tabular}{|l|} 
Scotland \\
\end{tabular} & FEf & $\mathrm{FWi}$ & & & FEf & F Wi & \multicolumn{2}{|c|}{ One } & FEf & $\mathrm{FWi}$ \\
\hline South Africa & FEf & $\mathrm{FWi}$ & & & & & \multicolumn{2}{|c|}{ Two } & \multicolumn{2}{|c|}{ Small scale } \\
\hline Sri Lanka & VEf & Wi & \multicolumn{2}{|c|}{ Some } & & & & & & \\
\hline Spain & VEf & $\mathrm{Wi}$ & VEf & F Wi & Ef & $\mathrm{VWi}$ & Ef & $\mathrm{FWi}$ & Ef $F$ & Wi \\
\hline Taiwan & FEf & F Wi & Ef & $\mathrm{FWi}$ & VEf & $\mathrm{Wi}$ & VEf & Wi & Ef & Wi \\
\hline Trinidad \& Tobago & & & Ef & Wi & & & & & & \\
\hline United States & Ef & $\mathrm{Wi}$ & Ef & $\mathrm{Wi}$ & Ef & $\mathrm{Wi}$ & Ef & $\mathrm{Wi}$ & & \\
\hline \begin{tabular}{|l|} 
Uruguay \\
\end{tabular} & VEf & $\mathrm{VWi}$ & \multirow{2}{*}{\multicolumn{2}{|c|}{$19=61 \%$}} & \multirow{2}{*}{\multicolumn{2}{|c|}{$17=55 \%$}} & & & & \\
\hline Totals $/ 31$ & \multicolumn{2}{|l|}{$26=$} & & & & & $15=$ & $48 \%$ & 10 & $32 \%$ \\
\hline
\end{tabular}

new optional geoscience courses are proving increasingly popular to 16-18 year olds, whilst recent revamps of the science curriculum in Australia and the Philippines has seen increased content of Earth science at all levels.

Elsewhere, some of the key comments recorded were as follows.

- Lack of support for school-level geoscience education from the science education community (biology, chemistry and physics).

- Lack of support for school-level geoscience education from geoscientists - particularly those in Higher Education.

- The teaching of school geoscience by non-specialist teachers (eg. specialists in geography, chemistry, etc.).

- Earth science being taught in poor, didactic ways with few examples, by non-specialist teachers.

- Lack of Earth science-focussed teacher training.

- Poor Earth science teaching resources.

- Lack of an internationally agreed Earth science curriculum promoted across the globe.

\section{A summary}

The data from the biased sample of the 32 counties included in the survey can be summarised as follows.

- Curricula - across the world, Earth science is included in science and geography curricula in a variety of different ways

- Standards - most countries have national standards for Earth science

- Global coverage - there is fairly good coverage of Earth science in the school curriculum globally - particularly for $7-16$ year olds
Table 10. The availability of Earth science outreach in Public Understanding organisations focussing on Earth science, local "rockhound" groups, groups aimed at children and Earth science content of local Public Understanding of Science events (the paler the shade, the less effective/widespread - where limited data are available, this is shown in white). (Key: $V=$ very; $F=$ fairly; $E f=$ effective; Wi = widespread)

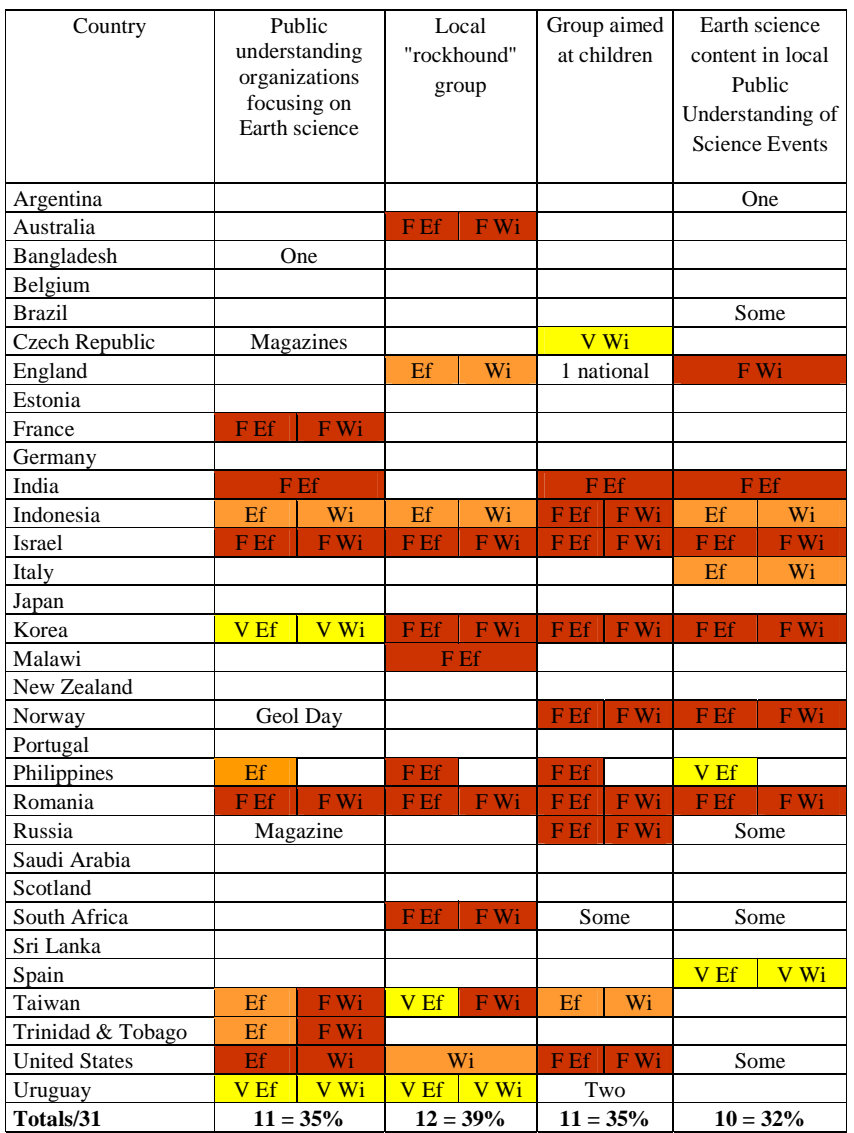

- Textbooks - more than half the textbooks for elementary students and more than a third of textbooks for high school students are of poor quality or are not available

- Benchmarking - a reasonably high number of geoscience terms is included in curricula across the world, with the numbers of terms increasing up the age range.

- Optional geoscience courses - these are available in schools/ colleges in more than half the countries surveyed - but mainly for small numbers of 16-18 year olds.

- Outreach - Earth science outreach across the globe is variable, with a wide variety of different programmes - however, it is difficult to discern a particular pattern of success

- Higher Education - the numbers of courses available to undergraduates and postgraduates appears to depend mainly on the level of development and size of the country concerned.

- Mentoring - lecturers in Higher Education institutions very rarely mentor school teachers.

Overall, the data indicates that most global developments in Earth science education at school level have been driven by enthusiastic individuals and groups. This being the case, it is not surprising that global development is very patchy. Nevertheless, a general improvement is probably discernible. 
Table 11. Records of successful Earth science outreach programmes across the world

\begin{tabular}{|c|c|}
\hline Country & Programme \\
\hline Argentina & Earth Science Week at the University of Buenos Aires \\
\hline Bangladesh & $\begin{array}{l}\text { - Bangladesh National Museum programmes } \\
\text { - Mobile educational programmes in some remote areas }\end{array}$ \\
\hline Belgium & $\begin{array}{l}\text { - Exposition "Dinosaures" - Musée des Sciences Naturelles - Bruxelles } \\
\text { - Exposition permanente - Musée africain Tervueren } \\
\text { - Expositions minéralogiques temporaires }\end{array}$ \\
\hline Brazil & “Caminhos Geologicos: Educacao em Geociencias" (“Geology tracks: Geoscience Education”) \\
\hline France & EDUSISMO LITHOTHEQUE \\
\hline India & Earth Science Olympiad \\
\hline Indonesia & $\begin{array}{l}\text { - Geoscience course for geography teachers conducted by universities, museums or government agencies. } \\
\text { - Talks to local government officers and community by universities or government agencies, especially related to } \\
\text { the community service programme of each institution. }\end{array}$ \\
\hline Israel & The Weizmann's programme \\
\hline Italy & $\begin{array}{l}\text { - Programs during the International Year of Planet Earth (IYPE) } \\
\text { - Earth Learning Idea translations }\end{array}$ \\
\hline Japan & Natural History Museums and Science Centres developed many programmes. \\
\hline Korea & $\begin{array}{l}\text { - Science centres operated by the 'Science Education and Science Research Institute (SESRI)' } \\
\text { - National science museum/centres located in metropolitan areas }\end{array}$ \\
\hline New Zealand & $\begin{array}{l}\text { - Language of the Rocks } \\
\text { - Univ. of Canterbury } \\
\text { - Most University outreach programmes } \\
\text { - Royal Society initiatives } \\
\text { - Te Papa museum programmes }\end{array}$ \\
\hline Norway & 5 year 'Geo programme' sponsored by Statoil http://www.naturfagsenteret.no/c1480828/seksjon.html?tid=1488151 \\
\hline Philippines & National Selection for the International Earth Science Olympiad (IESO) \\
\hline Portugal & Geology in summer \\
\hline Romania & National Geographic Competition \\
\hline Russia & $\begin{array}{l}\text { - Summer geological school } \\
\text { - Geographic Competitions at different levels }\end{array}$ \\
\hline South Africa & $\begin{array}{l}\text { - Cradle of Humankind } \\
\text { - Geological Museum at Museum Africa } \\
\text { - National Museum Bloemfontein Palaeontology } \\
\text { - Origins Centre - University of the Witwatersrand } \\
\text { - Sci-Bono Science Centre } \\
\text { - University of Bloemfontein/ EarthWise } \\
\text { - University of Kwa-Zulu Natal Science Centre } \\
\text { - University of Witwatersrand Geosciences Outreach }\end{array}$ \\
\hline Spain & $\begin{array}{l}\text { - Bi-annual meetings' on earth science teaching (organized by the AEPECT) } \\
\text { - Jornadas sobre Didáctica de Biología y Geología } \\
\text { - Summer geological trips } \\
\text { - Geolodays }\end{array}$ \\
\hline Sri Lanka & $\begin{array}{l}\text { - "Earth science for schools" teacher training workshops organized by Geological Society of Sri Lanka } \\
\text { - National Olympiad Competition for school students organized by Geological Society of Sri Lanka and the } \\
\text { Department of Geology, University of Peradeniya }\end{array}$ \\
\hline United States & $\begin{array}{l}\text { - Earth Science Week ( } 2^{\text {nd }} \text { week of October) sponsored by the American Geological Institute offers many groups } \\
\text { suggestions and opportunities to promote the Geosciences. } \\
\text { - Many groups and organisations work at local and regional levels to promote geoscience with varying success. }\end{array}$ \\
\hline
\end{tabular}


Table 12. Numbers of establishments offering undergraduate and graduate geoscience programmes

\begin{tabular}{|c|c|c|}
\hline Country & $\begin{array}{l}\text { How many offer under- } \\
\text { graduate degrees in the } \\
\text { geosciences or closely } \\
\text { related fields? }\end{array}$ & $\begin{array}{c}\text { How many offer geoscience } \\
\text { graduate (postgraduate) } \\
\text { degrees? }\end{array}$ \\
\hline Argentina & 14 & $\begin{array}{c}\text { All of them offer MSc } \\
\text { and PhD degrees and } \\
\text { orientation courses }\end{array}$ \\
\hline Australia & 16 & 16 \\
\hline Bangladesh & 3 & 3 \\
\hline Brazil & 34 & \\
\hline England & 20 & 20 \\
\hline Estonia & Yes & Yes \\
\hline Germany & 28 & 28 \\
\hline India & $\begin{array}{c}\text { A few - exact number } \\
\text { not known }\end{array}$ & $\begin{array}{l}\text { Several Master courses } \\
\text { in different areas } \\
\text { of geosciences }\end{array}$ \\
\hline Israel & 3 & 3 \\
\hline Italy & 29 & 29 \\
\hline Indonesia & 19 (State and Private) & 4 (State) \\
\hline Japan & \multicolumn{2}{|c|}{ Many } \\
\hline Korea & \multicolumn{2}{|c|}{ Many } \\
\hline Malawi & 1 & 1 \\
\hline New Zealand & 7 & 5 \\
\hline Norway & Approximately 9 & 9 \\
\hline Philippines & 5 & 1 \\
\hline Portugal & Yes & $\begin{array}{l}\text { Several Master courses } \\
\text { in different areas of } \\
\text { geosciences }\end{array}$ \\
\hline Russia & 36 & 36 \\
\hline Saudi Arabia & 3 & 2 \\
\hline Scotland & 5 & 5 \\
\hline South Africa & 10 & 10 \\
\hline Spain & $\begin{array}{l}10 \text { degrees in geology and } \\
7 \text { mining engineering }\end{array}$ & $\begin{array}{l}\text { All of them offer specific } \\
\text { postgraduate programs }\end{array}$ \\
\hline Sri Lanka & 5 & 2 \\
\hline Taiwan & 30 & 10 \\
\hline $\begin{array}{l}\text { Trinidad \& } \\
\text { Tobago }\end{array}$ & 1 & 0 \\
\hline United States & $\begin{array}{l}\text { More than } 600 \text { institu- } \\
\text { tions "have geology } \\
\text { programs, grant geology } \\
\text { degrees, or offer geology } \\
\text { courses" but not all } \\
\text { offer degrees }\end{array}$ & $\begin{array}{l}190 \text { programs that offer } \\
\text { Doctorate degrees and } 336 \\
\text { programs that offer a } \\
\text { Master degree in earth } \\
\text { science, geology and } \\
\text { environmental science. }\end{array}$ \\
\hline 27 countries & $\begin{array}{l}\text { Range from } 1 \text { to perhaps } \\
600 \text {; where definite figures } \\
\text { are available, mean of } 13\end{array}$ & $\begin{array}{c}\text { Range from } 1 \text { to } 336 ; \\
\text { where definite figures are } \\
\text { available (excluding US), } \\
\text { mean of } 10\end{array}$ \\
\hline
\end{tabular}

Despite this, there is no doubt that school-level geoscience education needs more support, in particular:

- the coordinated support of national geoscience communities (for example, by highlighting the contribution of school-level geoscience to undergraduate recruitment - see King, 2011a);

- the support of the international geoscience community;

- the raising of awareness with governments (for example, by highlighting the fact that some of the highest-performing countries in international comparisons in school science have Earth science as a substantial part of the curriculum, for example Japan, Korea and Taiwan (see King, 2011b);

- more resources and infrastructure to fund teacher training in geoscience education, particularly of the science and geography teachers who teach Earth science (eg. see King \& Thomas, 2012);

- more resources to fund the development and dissemination of high quality teaching resources;

- better global networking;

- better support for individuals and teams of enthusiasts in different regions and countries seeking to support and enhance the teaching of geoscience in their own communities.

There are success stories in school-level geoscience education across the globe, and these successes need to be celebrated, and the lessons learned from them distilled and disseminated worldwide, through active national and global support networks.

\section{Acknowledgements}

I personally, IGEO and IUGS-COGE, are all most grateful to the following for providing the data for the survey:

Argentina
Australia
Bangladesh
Belgium
Brazil

Czech Republic

England

Estonia

France

Germany

India

Indonesia

Israel

Italy

Japan

Korea

Malawi

New Zealand

Norway

Philippines

Portugal

Romania

Russia

Saudi Arabia
Jose Selles Martinez

Ian Clark

Afia Akhtar

A. Pissart

Celso Dal Ré Carneiro

Pedro Wagner Gonçalves

Petr Pudivítr

Chris King

Imbi Henno

Berenguer Jean-Luc

Sylke Hlawatsch, Dirk Felzmann

R. Shankar

Dwikorita (Rita) Karnawati

Hendra Amijaya

Nir Orion

Roberto Greco

Yoshisuke Kumano

Young-Shin Park

Cosmo Ngongondo

Glenn Vallender

Kari Beate Remmen

Merethe Frøyland

Miguel Cerna Cano

Luis Marques

Popa Mirela Mihaela

Evgeny Nestrov

Mohammed As'sad Tawfiq 
Table 13. The major problems facing geoscience education (free response)

\begin{tabular}{|c|c|}
\hline Country & What do you see as the major problems facing geoscience education in your country? \\
\hline Bangladesh & $\begin{array}{l}\text { - Lack of proper education for students to realize the importance of geoscience education and lack of initiative from } \\
\text { concerned people i.e., geoscientific community are the major problems. } \\
\text { - Moreover, low literacy rates and economic conditions are also problems facing geoscience education in our country. }\end{array}$ \\
\hline Estonia & . Estonia participated in TIMSS 2003. In geography Estonian students were the best in the world!!! \\
\hline Germany & $\begin{array}{l}\text { - The geography curricula emphasize anthropogeography. } \\
\text { - The curricula of biology, physics and chemistry barely focus on geoscience topics. } \\
\text { - Many geography teachers do not have a sound science education. } \\
\text { - The tradition of teaching geoscience topics in geography: very descriptive, quite idiographic, less process-oriented, less } \\
\text { connected to biology/ chemistry/ physics. }\end{array}$ \\
\hline India & $\begin{array}{l}\text { - Geoscience marketing is important because the scientific community doesn't realize the applications of geoscience. } \\
\text { - Geoscience careers should be made attractive so that the best talent can be attracted. } \\
\text { - Massive Funding is required to promote the subject. }\end{array}$ \\
\hline Indonesia & $\begin{array}{l}\text { - The curricula have been changed or modified several times; attention to improving the method of teaching and student } \\
\text { creativity seems to have been overlooked in each curriculum modification. } \\
\text { - Lack of teachers who can manage all subjects and lack of educational funding exacerbate the education problems. } \\
\text { We found the following deficiencies especially in geography: } \\
\text { - Topics are introduced too early and in too much detail in the elementary school (Year four elementary school). Too } \\
\text { much detailed information (but without real examples) make it difficult for pupils to understand. } \\
\text { - Some information concerning rock formation and rock classification are not correctly introduced to students. } \\
\text { - Lack of real and attractive examples, such as rock samples, slides, CDs, videos, field visits, make this subject un- } \\
\text { interesting and rather difficult to understand. } \\
\text { - Lack of available funds. } \\
\text { - All of the above deficiencies result in poor knowledge, poor understanding and poor appreciation by the public of } \\
\text { geoscience. Consequently, when there are any problems concerned with geological hazards, such as landslides, floods, } \\
\text { earthquakes, volcanic eruptions, it is hard to warn and protect the public. } \\
\text { Some other remarks are: } \\
\text { - Geoscience marketing is important because the community doesn't realize what geoscience is. } \\
\text { - Geoscience knowledge should be taught earlier in schools, beside the applied technology science. } \\
\text { - Educate the lecturers in the Universities and government officials on how to transfer geoscientific knowledge to the } \\
\text { entire community. } \\
\text { - Funds are needed for improving geoscience education for the community. }\end{array}$ \\
\hline Israel & $\begin{array}{l}\text { - Although there have been great effort s and successes with students and teachers, the implementation of earth science } \\
\text { education in Israel is still limited. } \\
\text { - The main reason for that is the science education establishment. This establishment is influenced strongly by } \\
\text { committees of scientists, who actually decide what will be taught in practice in schools. Unfortunately, those } \\
\text { committees are composed of scientists from physics, chemistry and biology. No earth scientist takes part in these } \\
\text { committees firstly because the leaders of these committees don't allowed this to happen and secondly because of the } \\
\text { earth scientists don't fight strongly enough to be included. } \\
\text { - As a result, whenever we succeed in raising our profile in schools, these committees respond with new decisions that } \\
\text { make teachers to stop teaching earth science. }\end{array}$ \\
\hline Korea & $\begin{array}{l}\text { - There are activities by those active in physics education, chemistry education, and biology education, but not earth } \\
\text { science or geo education. }\end{array}$ \\
\hline Malawi & $\begin{array}{l}\text { - Students are not adequately exposed to earth science at an early stage; Earth science as a subject is offered at } \\
\text { undergraduate level. This unawareness has led to the students thinking that geography is just the same as earth science. } \\
\text { The shortage of earth scientists in Malawi is obvious. }\end{array}$ \\
\hline New Zealand & $\begin{array}{l}\text { - Earth science continues to be a major issue in curriculum design. New Zealand is just beginning a review of the } \\
\text { national science curriculum in which earth science makes up the fourth strand. } \\
\text { - A key issue is teacher training and the role teacher training establishments play in this. There is no independent earth } \\
\text { science department dedicated to training the teaching of earth science. Indeed, the lack of teacher expertise in earth } \\
\text { science is a major concern, as is a lack of resources and funding. } \\
\text { - There is less focus on inquiry and laboratory investigation for geoscience. Fieldwork has been almost non-existent for } \\
\text { some time. } \\
\text { - External examination for geoscience has now been removed from Year } 11 \text { Science. Very few students nationally engage } \\
\text { with geoscience after year } 11 \text { (and numbers continue to decline at year 11). }\end{array}$ \\
\hline
\end{tabular}


Table 13. Contd...

\begin{tabular}{|c|c|}
\hline Country & What do you see as the major problems facing geoscience education in your country? \\
\hline Norway & $\begin{array}{l}\text { - Students choose the optional geoscience course because it is interesting and relevant for their understanding of the } \\
\text { news, e.g. earthquakes and extreme weather. The number of students choosing the optional subject is steadily } \\
\text { increasing every year. } \\
\text { - The Norway Center for Science Education has also been contacted by Sweden in order for them to learn about } \\
\text { Norwegian geoscience education; we are also in contact with Denmark }\end{array}$ \\
\hline Philippines & $\begin{array}{l}\text { - Because of the new K+12 curriculum, we need more educational resources to address the requirements of the } \\
\text { curriculum } \\
\text { - Also because of the new } \mathrm{K}+12 \text { curriculum, the Teacher Education institutions need restructuring. Specializations } \\
\text { must now include Earth Science, among others. But the problem will be the "experts' who will teach the Earth } \\
\text { Science subjects. }\end{array}$ \\
\hline Russia & $\begin{array}{l}\text { - To provide the baseline standards the Government has established standard curricula for the whole school, } \\
\text { "Introduction to the geology" within the subject of geography. } \\
\text { - However, geology in the standard of geography doesn't have enough teaching time. }\end{array}$ \\
\hline South Africa & $\begin{array}{l}\text { - Geosciences is unlikely to ever be taught as a main subject as there are simply too many competing well established } \\
\text { subjects } \\
\text { - Teacher training is required to strengthen the geosciences component of the subjects they are already teaching } \\
\text { - Museums out of school informal learning centres need assistance in developing high quality and assessed curriculum } \\
\text { related earth science programmes to support teaching in schools } \\
\text { - Continued interaction with committees responsible for drafting curriculum statements is required so that the } \\
\text { curriculum contains (in whatever subject) the essentials knowledge of Geosciences required by every citizen. } \\
\text { - [Internationally it would help if there could be agreement amongst Geoscience educators about what this knowledge is] } \\
\text { - At the tertiary level we have difficulty attracting good students into geosciences related fields- good students study } \\
\text { medicine, commerce, engineering etc. etc. Weaker students want to do geology because of the prospects of jobs in the } \\
\text { mineral industry } \\
\text { - At the tertiary level we have a problem of retiring academics with few candidates to replace them. Good postgraduates } \\
\text { are attracted into industry or to study overseas. } \\
\text { - With regard to teacher training- few geologists with the job prospects of the mineral industry enter into secondary } \\
\text { education or into teacher training- teacher trainers will often therefore, only have primary training in one or another } \\
\text { of science disciplines (biology or physical sciences) }\end{array}$ \\
\hline Sri Lanka & $\begin{array}{l}\text { The main problems in promoting geoscience education in Sri Lanka are: } \\
\text { - geoscience is not taught as a main subject in school curriculum, } \\
\text { - lack of awareness of geosciences among school students, } \\
\text { - lack of awareness about geoscience-related job opportunities, } \\
\text { - shortage of earth science learning materials in schools, etc. }\end{array}$ \\
\hline $\begin{array}{l}\text { Trinidad \& } \\
\text { Tobago }\end{array}$ & $\begin{array}{l}\text { - The high stakes 'end of primary' exam only tests math and language skills so many schools opt to teach little or no } \\
\text { social studies and science in the two years preceding this exam. }\end{array}$ \\
\hline
\end{tabular}

Scotland

South Africa

Sri Lanka

Spain

Taiwan

Trinidad \& Tobago

Uruguay

United States
Colin Graham, Hamish Ross

Ian McKay

Ashvin Wickramasooriya

A. Pitawala

Xavier Juan

Chun-Yen Chang

Stacey Edwards

Fernando Tabó

Mary Dowse, Sharon Locke

\section{References}

King, C. J. H., 2010, An Analysis of Misconceptions in Science Textbooks: Earth science in England and Wales. International Journal of Science Education, v. 32, no. 5, pp. 565-601.

King, C., 2011a, What does it mean to be a trained geology teacher? - and what should we do to keep training geology teachers?

Teaching Earth Sciences, v. 36, no. 2, pp. 52-55.

King, C., 2011b, Where should Earth science be situated in the curriculum? Teaching Earth Sciences, v. 36, no. 2, pp. 56-60.

King, C. \& Thomas, A., 2012, ESEU: report on the 2-year pilot and 10-year national rollout. ESEU Internal Report, April 2012. (available from the author)

International Geoscience Education Organisation (IGEO) website: http://www.geoscied.org/, 'About the IGEO' section, last accessed December 2012. 